\title{
Analisis Satuan Kemampuan Lahan Untuk Pengembangan Kawasan Pariwisata di Kabupaten Tabalong
}

\author{
Analysis of Land Capability Unit for the Development of Tourism Areas in \\ Tabalong Regency
}

\author{
Erlangga Kautsar ${ }^{\mathrm{a}}$, Misha Dwina Irani Sobba ${ }^{\mathrm{a}}$, Nurul Pertiwi ${ }^{\mathrm{a}}$, Trisha Agustine ${ }^{\mathrm{a} *}$ \\ ${ }^{a}$ Institut Teknologi Kalimantan, Balikpapan, Indonesia
}

\begin{abstract}
Abstrak
Kabupaten Tabalong berada diantara Provinsi Kalimantan Timur dan Kalimantan Tengah. Kabupaten Tabalong memiliki potensi menjadi kawasan pariwisata yang terbagi menjadi 3 jenis wisata yaitu wisata alam, buatan, budaya, dan buatan. Tujuan penelitian ini adalah untuk mengetahui kesesuaian lahan dan daya dukung kawasan wisata tersebut. Metode penelitian yang digunakan dalam penelitian ini yaitu metode analisis deskriptif kuantitatif untuk mengolah dan menafsirkan data yang diperoleh dan metode analisis spasial untuk melihat kemampuan lahan. Hasil penelitian menunjukkan Kabupaten Tabalong didominasi oleh lahan dengan kemampuan pengembangan wisata rendah, selanjutnya diikuti oleh lahan dengan kemampuan pengembangan wisata sedang. Hanya sebagian kecil wilayah di Kabupaten Tabalong dengan kemampuan pengembangan wisata sangat rendah. Kesimpulan dari penelitian ini diketahui bahwa Kabupaten Tabalong tergolong dalam kemampuan lahan pengembangan rendah, dan terdapat 13 objek wisata yang memiliki kesesuaian lahan dan fisik, serta terdapat 10 objek daya tarik wisata yang tidak sesuai dengan kemampuan lahan.
\end{abstract}

Kata kunci: Kemampuan lahan, Objek wisata, Pengembangan wisata.

\begin{abstract}
Tabalong regency is located between East Kalimantan and Central Kalimantan Provinces. This area has the potential to be a tourism area that is divided into 3 types of tourism, artificial, cultural, and aesthetical. The purpose of this research is to know the land suitability and the carrying capacity of these tourist areas. The research method used for this research is a quantitative descriptive analysis method for processing data and the results showed that Tabalong Regency was dominated by land with low development capability, followed by land with the ability of tourist development. And there are 10 attraction that are not in accordance with the ability of land.
\end{abstract}

Keyword: Land capability, Tourist attraction, Tourism development.

\section{Pendahuluan}

Pengembangan sektor pariwisata di Provinsi Kalimantan Selatan mengalami peningkatan di tiap tahunnya. Hal ini dapat terlihat dari data jumlah wisatawan mancanegara yang berkunjung ke Kalimantan Selatan pada tahun 2018 sebanyak 30.586 orang, sedangkan wisatawan nusantara sejumlah 761.428 orang (Dinas Pariwisata Provinsi Kalimantan Selatan, 2019). Data di tahun 2018 tersebut terlihat meningkat daripada tahun 2017. Peningkatan kunjungan wisatawan domestik dan mancanegara merupakan suatu pencapaian yang besar untuk pemerintah Provinsi Kalimantan Selatan. Potensi pariwisata yang ada dapat memberikan

\footnotetext{
* Corresponding author. Nurul Pertiwi

E-mail address: nurulpertiwi09@gmail.com.
} 
dampak positif bagi semua pihak baik perhotelan, transportasi, dan tentunya bagi masyarakat Kalimantan Selatan sendiri.

Dalam upaya pengembangan sektor pariwisata dapat dilakukan sebagaimana sektor lainnya yakni dapat dilakukan sebuah perencanaan terlebih dahulu. Evaluasi potensi pada suatu kawasan perlu dinilai agar penggunaan lahan untuk pariwisata dapat dilakukan secara optimal. Pentingnya informasi tentang kualitas sumber daya alam untuk tidak terjadi persaingan dalam penggunaan lahan di kawasan pariwisata. Penggunaan lahan untuk keperluan pariwisata maupun non-pariwisata terus meningkat sejalan dengan semakin meningkatnya jumlah penduduk.

Penentuan lokasi yang sesuai perlu dilakukan evaluasi sumber daya lahan. Evaluasi sumber daya lahan pada hakekatnya merupakan proses untuk mengetahui potensi sumber daya lahan untuk berbagai penggunaan. Kemampuan lahan dinilai untuk mendukung pengembangan pariwisata. Menurut Luther Selfie tahun 2016, kemampuan lahan merupakan penilaian atas kemampuan lahan untuk penggunaan tertentu yang dinilai masing-masing faktor penghambat. Penilaian kemampuan lahan menjadi acuan dalam pemanfaatan lahan, sehingga tetap menjadikan hasil yang optimum dan tetap menjadi kelestarian ekologi (Arsyad, 2010). Penggunaan lahan yang tidak sesuai dengan kemampuannya dan tidak dibarengi oleh pengelolaan yang baik akan mempercepat terjadinya degradasi lahan. Apabila sudah mengalami degradasi lahan, maka akan berpengaruh pada tingkat produktivitas lahan yang menurun (Arsyad, 2010). Jenis penggunaan lahan yang sesuai dapat dilakukan dengan mengetahui jenisjenis pembatasnya agar berfungsi secara lestari. Pendekatan ini diperlukan karena keterbatasan luas lahan yang tersedia untuk memenuhi segala jenis kebutuhan dalam suatu wilayah (Roimaltus,dkk, 2019).

Kabupaten Tabalong ialah salah satu wilayah yang berada di Provinsi Kalimantan Selatan dengan luas sebesar 3.575,53 $\mathrm{km}^{2}$. Letak geografis Kabupaten Tabalong berada diantara Provinsi Kalimantan Timur dan Kalimantan Tengah, sehingga menjadikannya jalur segitiga emas dengan Provinsi Kalimantan Selatan. Adanya potensi pariwisata yang dimiliki oleh Kabupaten Tabalong, hal ini dapat dilihat dari banyaknya kawasan pariwisata yang ada yakni 35 unit. Adapun jenis pariwisata tersebut dibagi dalam 4 jenis yaitu wisata alam, buatan, budaya, dan religi. Pertumbuhan aktivitas wisatawan harus sejalan dengan kelestarian lingkungan karena yang terjadi adalah aktivitas pengunjung menyebabkan penurunan kualitas lingkungan (Roimaltus,dkk, 2019).

Pesatnya laju pembangunan dan pertambahan penduduk di Kabupaten Tabalong menjadi ancaman terhadap sumber daya alam dan ekosistem semakin meningkat. Kegiatan pariwisata yang semakin tinggi, harus dibarengi dengan kesadaran untuk mengelola alam dengan baik sehingga akan tetap terjaga. Oleh karena itu, perlu adanya pengendalian pemanfaatan ruang untuk menjaga kelestarian alam. Untuk itu, dalam penelitian ini bertujuan untuk menganalisis kemampuan lahan di Kabupaten Tabalong.

\section{Metode}

Adapun teknik atau metode analisis yang digunakan adalah teknik analisis deskriptif kuantitatif untuk mengolah dan menafsirkan data yang diperoleh dan metode analisis spasial untuk melihat kemampuan lahan. Analisis spasial dari hasil overlay peta sebagai visualisasi hasil pengklasifikasian kemampuan lahan. Data yang diperlukan diperoleh dari BAPPEDA Kabupaten Tabalong tahun 2018.

Masing-masing SKL memiliki pembobotan sesuai dengan yang tertera pada Peraturan Menteri Pekerjaan Umum No.20/PRT/M.2007. Adapun bobot masing-masing satuan kemampuan lahan adalah sebagai berikut:

Tabel 1. Pembobotan Masing-Masing Satuan Kemampuan Lahan (SKL) (Peraturan Menteri Pekerjaan Umum No.20/PRT/M/2007)

\begin{tabular}{ccc}
\hline No. & Satuan Kemampuan Lahan & Bobot \\
\hline $\mathbf{1}$ & SKL Morfologi & 5 \\
$\mathbf{2}$ & SKL Kemudahan Dikerjakan & 1 \\
$\mathbf{3}$ & SKL Kestabilan Lereng & 5 \\
\hline
\end{tabular}




\begin{tabular}{ccc}
\hline No. & Satuan Kemampuan Lahan & Bobot \\
\hline $\mathbf{4}$ & SKL Kestabilan Pondasi & 3 \\
$\mathbf{5}$ & SKL Ketersediaan Air & 5 \\
$\mathbf{6}$ & SKL Terhadap Erosi & 3 \\
$\mathbf{7}$ & SKL Untuk Drainase & 5 \\
$\mathbf{8}$ & SKL Pembuangan Limbah & 0 \\
$\mathbf{9}$ & SKL Bencana Alam & 5 \\
\hline
\end{tabular}

\section{Kajian literatur}

\subsection{Definisi Kemampuan Lahan}

Menururt FAO (1976) Kemampuan lahan merupakan usaha yang paling intensif yang termasuk juga tindakan pengelolaannya tanpa menyebabkan tanahnya menjadi rusak dalam jangka waktu yang terbatas. lahan yang mempunyai kemampuan yang baik memiliki sifat fisik dan kimia yang sesuai dengan kebutuhan tanaman sehingga akan mampu mendukung pertumbuhan dan produksi tanaman secara optimal dan berkesinambungan.

\subsection{Analisis Satuan Kemampuan Lahan}

Dalam Peraturan Menteri Pekerjaan Umum No.20/PRT/M.2007 tentang Pedoman Teknik Analisis Fisik Dan Lingkungan, Ekonomi Serta Sosial Budaya dalam Penyusunan Rencana Tata Ruang menjelaskan bahwa analisis ini dilakukan untuk mengetahui seberapa besar kemampuan lahan untuk dapat mendukung upaya pemanfaatan lahan di Kabupaten Tabalong. Analisis kemampuan lahan ini sekaligus untuk mengetahui faktor-faktor fisik lahan yang bersifat menghambat dan tidak menghambat dalam pemanfaatan lahan di Kabupaten Tabalong. Output (keluaran) dari analisis ini adalah berupa peta kelas kemampuan lahan (zonasi) yang terdiri dari kawasan kemungkinan (pengembangan), kawasan kendala dan kawasan limitasi sebagai gambaran dari tingkatan kemampuan lahan pada daerah perencanaan. Analisis kemampuan lahan ini bermaksud untuk mengkaji tingkatan kemampuan lahan untuk mengkaji tingkatan kemampuan lahan pada daerah studi berdasarkan aspek fisik dasar. Aspek fisik dasar merupakan salah satu materi yang diperlukan dalam rencana pengembangan suatu kota.

Menurut Peraturan Menteri Pekerjaan Umum No.20/PRT/M.2007 tentang Pedoman Teknik Analisis Fisik Dan Lingkungan, Ekonomi Serta Sosial Budaya dalam Penyusunan Rencana Tata Ruang adapun aspek-aspek fisik satuan kemampuan lahan tersebut dalam analisis ini dikenal dengan satuan kemampuan lahan yang pertama satuan kemampuan lahan morfologi yang membutuhkan peta morfologi dan peta kelerengan. Selanjutnya satuan kemampuan lahan kemudahan dikerjakan yang membutuhkan peta topografi, peta kelerengan, dan peta jenis tanah. Kemudian, satuan kemampuan lahan kestabilan lereng membutuhkan peta topografi, peta kelerengan dan peta morfologi. Kemudian, satuan kemampuan lahan kestabilan pondasi membutuhkan peta topografi, peta kelerengan, peta morfologi, dan peta jenis tanah. Kemudian, satuan kemampuan lahan ketersediaan air membutuhkan peta curah hujan dan peta guna lahan. Lalu, satuan kemampuan lahan drainase membutuhkan peta ketinggian, peta kemiringan dan peta curah hujan. Selanjutnya, satuan kemampuan lahan terhadap erosi membutuhkan peta curah hujan, peta jenis tanah, peta morfologi, dan peta kemiringan. Selanjutnya, satuan kemampuan lahan pembuangan limbah membutuhkan peta ketinggian, peta kemiringan, peta curah hujan dan peta guna lahan. Selanjutnya, yang terakhir yaitu satuan kemampuan lahan terhadap bencana alam membutuhkan peta gerakan tanah dan peta gempa bumi.

\subsection{Karakteristik Lokasi dan Kesuaian Lahan Kawasan Pariwisata}

Karakteristik lokasi dan kesesuaian lahan kawasan pariwisata berdasarkan Peraturan Menteri Pekerjaan Umum Nomor 41 Tahun 2007 tentang Pedoman Kriteria Teknis Kawasan Budidaya meliputi:

1.Memiliki struktur tanah yang stabil 
2.Memiliki kemiringan tanah yang memungkinkan dibangun tanpa memberikan dampak negatif terhadap kelestarian lingkungan.

3.Merupakan lahan yang tidak terlalu subur dan bukan lahan pertanian yang produktif.

4. Memiliki aksesibilitas yang tinggi.

5.Tidak mengganggu kelancaran lalu lintas pada jalur jalan raya regional.

6.Tersedia prasarana fisik yaitu listrik dan air bersih.

7.Terdiri dari lingkungan/bangunan/gedung bersejarah dan cagar budaya.

8. Memiliki nilai sejarah, ilmu pengetahuan dan budaya, serta keunikan tertentu.

9.Dilengkapi fasilitas pengolah limbah (padat dan cair).

\section{Hasil dan Pembahasan}

Hasil dari analisis kemampuan lahan dalam pengembangan pariwisata di Kabupaten Tabalong, diperoleh hasil sebagai berikut:

Tabel 2. Kemampuan Lahan Kabupaten Tabalong (Analisis Penulis, 2019)

\begin{tabular}{ccccccccccc}
\hline Penilaian & A & B & C & D & E & F & G & H & I & Kemampuan Lahan \\
\cline { 2 - 9 } Bobot & $\mathbf{5}$ & $\mathbf{1}$ & $\mathbf{5}$ & $\mathbf{3}$ & $\mathbf{5}$ & $\mathbf{5}$ & $\mathbf{3}$ & $\mathbf{0}$ & $\mathbf{5}$ & Total Nilai \\
$\quad \mathbf{x}$ & 1 & 5 & 3 & 5 & 5 & 9 & 0 & 5 & 28 \\
Nilai & 10 & 2 & 10 & 6 & 10 & 10 & 9 & 0 & 10 & 57 \\
& 15 & 3 & 15 & 9 & 15 & 15 & 9 & 0 & 15 & 96 \\
& 20 & 4 & 20 & 12 & 20 & 20 & 12 & 0 & 20 & 108 \\
& 25 & 5 & 25 & 15 & 25 & 25 & 15 & 0 & 25 & 160 \\
\hline
\end{tabular}

Keterangan :

A : SKL Morfologi,

B : SKL Kemudahan Dikerjakan,

C : SKL Kestabilan Lereng,

D : SKL Kestabilan Pondasi,

E : SKL Ketersediaan Air,

F : SKL Drainase,

G : SKL terhadap Erosi,

$\mathrm{H}$ : SKL Pembuangan Limbah,

I : SKL Bencana Alam

Kemampuan lahan dilakukan dalam 9 SKL (Satuan Kemampuan Lahan), hasil dari setiap SKL akan diuraikan sebagai berikut:

1. Dari hasil analisis kemampuan lahan yang dilakukan terhadap 9 jenis SKL didapatkan bahwa untuk kondisi SKL morfologi atau bentang alam di Kabupaten Tabalong didominasi oleh kemampuan morfologi rendah yang tersebar di seluruh kecamatan yaitu Kecamatan Bintang Ara, Jaro, Muara Uya, Haruai, Upau, Tanjung, Murung Pudak, Banua Lawas, Kelua, Pugaan, Muara Harus, dan Tanta dengan luas lahan sebesar 122.460 Ha. Dapat diperjelas dengan tabel sebagai berikut.

Tabel 3. Luas Lahan Tiap klasifikasi SKL Morfologi (Analisis Penulis, 2019)

\begin{tabular}{ccc}
\hline No. & Klasifikasi Satuan Kemampuan Lahan & Luas (Ha) \\
\hline $\mathbf{1}$ & Kemampuan Lahan dar Morfologi Tinggi & 8.534 \\
$\mathbf{2}$ & Kemampuan Lahan dar Morfologi Cukup & 11.0204 \\
$\mathbf{3}$ & Kemampuan Lahan dar Morfologi Sedang & 94.609 \\
$\mathbf{4}$ & Kemampuan Lahan dar Morfologi Kurang & 21.360 \\
$\mathbf{5}$ & Kemampuan Lahan dar Morfologi Rendah & 122.460 \\
\hline
\end{tabular}


2. Kemudian untuk hasil dari SKL kemudahan dikerjakan pada Kabupaten Tabalong didominasi oleh kemampuan kemudahan untuk dikerjakan sedang yang tersebar di sebagian kecamatan yaitu Kecamatan Bintang Ara, Jaro, Muara Uya, Haruai, Upau, Tanjung, Murung Pudak, Tanta, Muara Harus dengan luas wilayah 260.399 Ha. Dapat diperjelas dengan tabel sebagai berikut.

Tabel 4. Luas Lahan Tiap klasifikasi SKL Kemudahan Dikerjakan (Analisis Penulis, 2019)

\begin{tabular}{clc}
\hline No. & Klasifikasi Satuan Kemampuan Lahan & Luas (Ha) \\
\hline $\mathbf{1}$ & Kemudahan Dikerjakan Kurang & 32.165 \\
$\mathbf{2}$ & Kemudahan Dikerjakan Sedang & 260.399 \\
$\mathbf{3}$ & Kemudahan Dikerjakan Cukup & 63.083 \\
\hline
\end{tabular}

3. Pada SKL kestabilan lereng di Kabupaten Tabalong terdiri dari kestabilan lereng kurang, sedang, dan tinggi. Sementa itu, kestablan lereng didominasi kestabilan lereng sedang yang tersebar di sebagian kecamatan yaitu Kecamatan Bintang Ara, Jaro, Muara Uya, Haruai, Upau, Tanjung, Murung Pudak, Banua Lawas, dan Kelua dengan luas wilayah 216.203 Ha. Dapat diperjelas dengan tabel sebagai berikut.

Tabel 5. Luas Lahan Tiap klasifikasi SKL Kestabilan Lereng (Analisis Penulis, 2019)

\begin{tabular}{clr}
\hline No. & Klasifikasi Satuan Kemampuan Lahan & Luas (Ha) \\
\hline $\mathbf{1}$ & Kestabilan Lereng Kurang & 1.943 \\
$\mathbf{2}$ & Kestabilan Lereng Sedang & 216.203 \\
$\mathbf{3}$ & Kestabilan Lereng Tinggi & 134.872 \\
\hline
\end{tabular}

4. Selanjutnya pada klasifikasi SKL kestabilan pondasi di Kabupaten Tabalong terdiri dari klasifikasi kestabilan pondasi kuran dan kestabilan pondasi tinggi. Sementara itu, kestabilan pondasi didominasi oleh kemampuan daya dukung dan kestabilan pondasi kurang yang tersebar di Kecamatan Tanjung, Kelua, Banua Lawas, Pugaan, Haruai, Upau, Jaro, Muara Uya, dan Bintang Ara dengan luas wilayah 184.306 Ha.. Wilayah lainnya juga memiliki kemampuan daya dukung dan kestabilan pondasi tinggi. Dapat diperjelas dengan tabel sebagai berikut.

Tabel 6. Luas Lahan Tiap klasifikasi SKL Kestabilan Pondasi (Analisis Penulis, 2019)

\begin{tabular}{clc}
\hline No. & Klasifikasi Satuan Kemampuan Lahan & Luas (Ha) \\
\hline $\mathbf{1}$ & Kestabilan Pondasi Kurang & 184.306 \\
$\mathbf{2}$ & Kestabilan Pondasi Tinggi & 167.362 \\
\hline
\end{tabular}

5. Kemudian untuk SKL ketersediaan air di Kabupaten Tabalong memiliki klasifikasikan keterseiaan air sedang dan ketersediaan air tinggi. Sementara itu, klasifikasi ketersediaan air didominasi oleh ketersediaan air tinggi yang tersebar di seluruh kecamatan yaitu Kecamatan Bintang Ara, Jaro, Muara Uya, Haruai, Upau, Tanjung, Murung Pudak, Banua Lawas, Kelua, Pugaan, Muara Harus, dan Tanta dengan luas wilayah 323.513 Ha. Dapat diperjelas dengan tabel sebagai berikut.

Tabel 7. Luas Lahan Tiap klasifikasi SKL Ketersediaan Air (Analisis Penulis, 2019)

\begin{tabular}{ccc}
\hline No. & Klasifikasi Satuan Kemampuan Lahan & Luas (Ha) \\
\hline $\mathbf{1}$ & Ketersediaan Air Sedang & 32.165 \\
$\mathbf{2}$ & Ketersediaan Air Tinggi & 323.513 \\
\hline
\end{tabular}


6. Pada SKL drainase di Kabupaten Tabalong terdiri dari klasifikasi drainase cukup dan drainase tinggi. Sementara itu, klasifikasi drainase didominasi oleh drainase tinggi yang tersebar di seluruh kecamatan yaitu Kecamatan Bintang Ara, Jaro, Muara Uya, Haruai, Upau, Tanjung, Murung Pudak, Banua Lawas, Kelua, Pugaan, Muara Harus, dan Tanta dengan luas wilayah 263.786 Ha. Dapat diperjelas dengan tabel sebagai berikut.

Tabel 8. Luas Lahan Tiap klasifikasi SKL Drainase (Analisis Penulis, 2019)

\begin{tabular}{clc}
\hline No. & Klasifikasi Satuan Kemampuan Lahan & Luas (Ha) \\
\hline $\mathbf{1}$ & Drainase Cukup & 91.784 \\
$\mathbf{2}$ & Drainase Tinggi & 263.786 \\
\hline
\end{tabular}

7. Selanjutnya pada SKL terhadap erosi di Kabupaten Tabalong terdiri dari klasifikasi erosi cukup tinggi, erosi sedang, dan erosi rendah. Sementara itu, klasifikasi terhadap erosi didominasi oleh tingkat erosi sedang yang tersebar di seluruh kecamatan yaitu Kecamatan Bintang Ara, Jaro, Muara Uya, Haruai, Upau, Tanjung, Murung Pudak, Banua Lawas, Kelua, Pugaan, Muara Harus, dan Tanta dengan luas wilayah 146.044 Ha. Dapat diperjelas dengan tabel sebagai berikut.

Tabel 9. Luas Lahan Tiap klasifikasi SKL Terhadap Erosi (Analisis Penulis, 2019)

\begin{tabular}{clc}
\hline No. & Klasifikasi Satuan Kemampuan Lahan & Luas (Ha) \\
\hline $\mathbf{1}$ & Erosi Cukup Tinggi & 118.575 \\
$\mathbf{2}$ & Erosi Sedang & 146.044 \\
$\mathbf{3}$ & Erosi Rendah & 91.061 \\
\hline
\end{tabular}

8. Untuk hasil dari SKL pembuangan limbah di Kabupaten Tabalong terdiri dari kemampuan lahan untuk pembuangan limbah rendah, pembuangan limbah sedang, dan pembuangan limbah cukup. Sementara itu, klasifikasi pembuangan limbah didominasi oleh pembuangan limbah sedang. Wilayah lainnya juga memiliki pembuangan limbah cukup dan sedang yang tersebar di seluruh kecamatan yaitu Kecamatan Bintang Ara, Jaro, Muara Uya, Haruai, Upau, Tanjung, Murung Pudak, Banua Lawas, Kelua, Pugaan, Muara Harus, dan Tanta dengan luas wilayah 221.789 Ha. Dapat diperjelas dengan tabel sebagai berikut.

Tabel 10. Luas Lahan Tiap klasifikasi SKL Pembuangan Limbah (Analisis Penulis, 2019)

\begin{tabular}{ccc}
\hline No. & Klasifikasi Satuan Kemampuan Lahan & Luas (Ha) \\
\hline $\mathbf{1}$ & Kemampuan Lahan Untuk Pembuangan Limbah Rendah & 25.625 \\
$\mathbf{2}$ & Kemampuan Lahan Untuk Pembuangan Limbah Sedang & 221.789 \\
$\mathbf{3}$ & Kemampuan Lahan Untuk Pembuangan Limbah Cukup & 108.215 \\
\hline
\end{tabular}

9. Kemudian yang terakhir, hasil dari SKL terhadap bencana di Kabupaten Tabalong terdiri dari potensi bencana alam tinggi, bencana alam cukup, dan bencana alam kurang. Sementara itu, klasifikasi potensi bencana alam didominasi oleh potensi bencana alam cukup yang tersebar di kecamatan yaitu Kecamatan Bintang Ara, Jaro, Muara Uya, Haruai, Upau, Tanjung, Murung Pudak, Banua Lawas, Kelua, dan Tanta dengan luas wilayah 185.872 Ha. Dapat diperjelas dengan tabel sebagai berikut.

Tabel 11. Luas Lahan Tiap klasifikasi SKL Terhadap Bencana (Analisis Penulis, 2019)

\begin{tabular}{clc}
\hline No. & Klasifikasi Satuan Kemampuan Lahan & Luas (Ha) \\
\hline $\mathbf{1}$ & Potensi Bencana Alam Tinggi & 1.943 \\
$\mathbf{2}$ & Potensi Bencana Alam Cukup & 185.872 \\
$\mathbf{3}$ & Potensi Bencana Alam Kurang & 165.310 \\
\hline
\end{tabular}


Langkah awal dalam analisa kemampuan lahan telah dilakukan pada analisa satuan-satuan kemampuan lahan. Total nilai yang dikalikan dengan bobot masing-masing kemampuan lahan akan menghasilkan klasifikasi berupa zona-zona pengembangan lahan di Kabupaten Tabalong. Peta masing-masing SKL juga akan di-superimpose sehingga didapatkan nilai kemampuan lahan di wilayah perencanaan. Selanjutnya, untuk mengetahui klasifikasi kemampuan lahan di Kabupaten Tabalong dapat dilihat pada tabel sebagai berikut.

Tabel 12. Klasifikasi Pengembangan Lahan Kabupaten Tabalong (Analisis Penulis, 2019)

\begin{tabular}{cccc}
\hline Bobot & Klasifikasi & Keterangan & Arahan Pengembangan \\
\hline $\mathbf{2 8 - 5 4}$ & Kelas E & $\begin{array}{c}\text { Kemampuan Pengembangan Sangat } \\
\text { Rendah }\end{array}$ & $\begin{array}{c}\text { Kawasan lindung atau kawasan } \\
\text { resapan Air }\end{array}$ \\
$\mathbf{5 5 - 8 0}$ & Kelas D & Kemampuan Pengembangan Rendah & $\begin{array}{c}\text { Kawasan penyangga, kawasan lindung, } \\
\text { atau kawasan resapan air }\end{array}$ \\
$\mathbf{8 1 - 1 0 7}$ & Kelas C & $\begin{array}{c}\text { Kemampuan Pengembangan Sedang } \\
\text { Kawasan terbangun dengan kegiatan } \\
\text { tertentu }\end{array}$ \\
$\mathbf{1 0 8 - 1 3 4}$ & Kelas B & $\begin{array}{c}\text { Kemampuan Pengembangan Agak } \\
\text { Tinggi }\end{array}$ & $\begin{array}{c}\text { Kawasan terbangun dengan berbagai } \\
\text { kegiatan }\end{array}$ \\
$\mathbf{1 3 5 - 1 6 0}$ & Kelas A & $\begin{array}{c}\text { Kemampuan Pengembangan Sangat } \\
\text { Tinggi }\end{array}$ & $\begin{array}{c}\text { Daerah terbangun udiatas empat lantai } \\
\text { untuk berbagai kegiatan }\end{array}$ \\
\hline
\end{tabular}

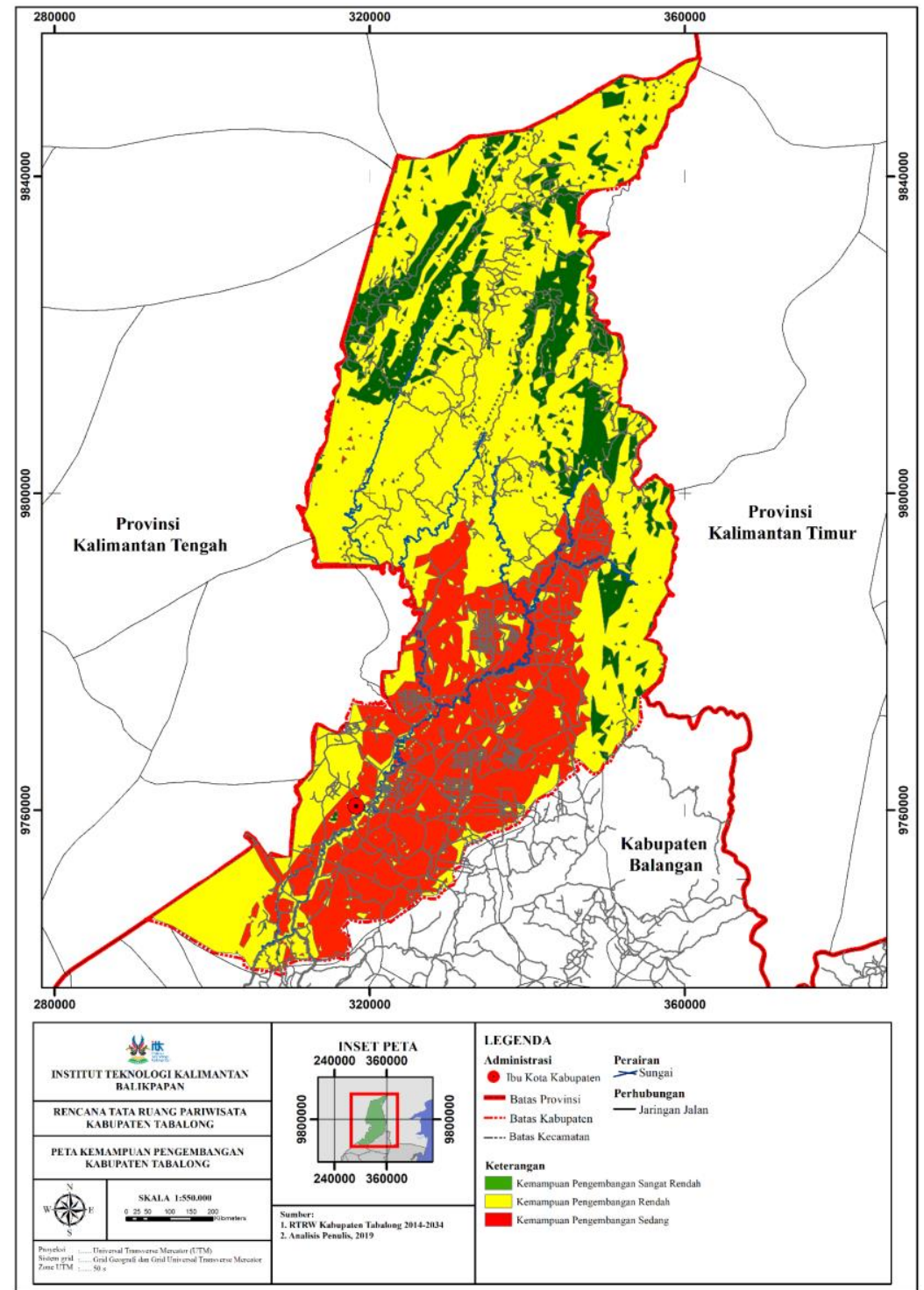

Gambar 1. Peta Kemampuan Lahan Kabupaten Tabalong (Hasil Analisis, 2019) 
Berdasarkan peta kemampuan lahan yang telah didapatkan, maka selanjutnya melakukan klasifikasi kemampuan pengembangan lahan terhadap ODTW (Objek Daya Tarik Wisata) di Kabupaten Tabalong, dimana dapat disimpulkan bahwa klasifikasi kemampuan pengembangan lahan di Kabupaten Tabalong terdiri diri kemampuan pengembangan sangat rendah, rendah, dan sedang. Kemampuan pengembangan lahan pada lingkup Kabupaten Tabalong didominasi dengan kemampuan pengembangan rendah sebesar 205.732 Ha. Kemampuan pengembangan sangat rendah sebesar 44844 Ha. Sedangkan, Kemamuan pengembangan sedang sebesar 97869 Ha.

Setelah mendapatkan hasil analisis terkait kemampuan pengembangan lahan beserta arahan pengembangan, maka selanjutnya dilakukan analisis overlay peta pengembangan lahan dengan persebaran titik objek daya tarik wisata, untuk mengetahui lokasi tiap objek daya tarik wisata terhadap peta kemampuan pengembangan lahan, yang selanjutnya akan digunakan untuk keperluan analisis kesesuaian lahan, berikut merupakan peta overlay kemampuan pengembangan lahan dengan titik objek daya tarik wisata.

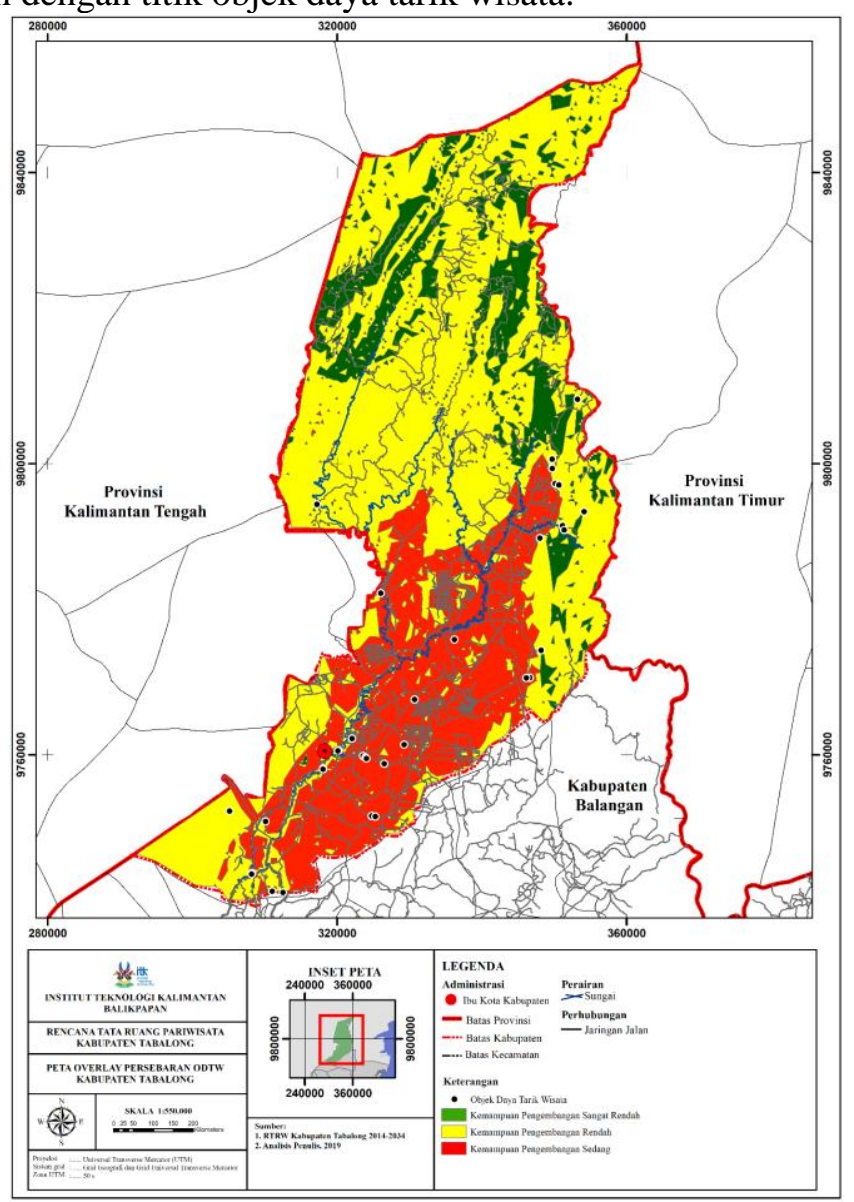

Gambar 2. Peta Overlay Kemampuan Pengembangan Lahan dengan Objek Daya Tarik Wisata (Hasil Analisis, 2019)

Dari peta diatas dapat diketahui bahwa titik objek daya tarik wisata lebih banyak terletak pada kemampuan pengembangan rendah dengan arahan kawasan penyangga, kawasan lindung, atau kawasan resapan air dan terdapat dua objek daya yang terletak pada kemampuan pengembangan sangat rendah dengan arahan kawasan lindung atau kawasan resapan air yaitu pada objek wisata Puncak Karamo dan Sungai Batu Rapai.

Berdasarkan hasil analisis kemampuan lahan dan analisis overlay yang telah ditampilkan, maka dapat diketahui bagaimana kesesuaian lahan dengan lokasi eksisting objek dan daya tarik wisata yang didasarkan pada karakteristik lokasi kawasan pariwisata di Kabupaten Tabalong. Hasil analisis kesesuaian lahan terhadap 35 objek wisata yang terdapat di Kabupaten tabalong dapat diketahui bahwa terdapat 13 objek daya tarik wisata yang memiliki kesesuaian kemampuan lahan dan fisik, tetapi terdapat 10 objek daya tarik wisata yang tidak sesuai degan kemampuan lahan diantaranya Taman Bunga Poska, Taman 10-K, Taman Giat, Taman Bunga dan Buah, Makam Penghulu Rasyid, Masjid Pusaka, Masjid Islamic Center, Makam Datu 
Puain, Masjid Pusaka Nurul Iman, dan Seribu Cahaya Badudus dan Babarasih Pusaka.. Untuk kesesuaian sarana dan prasarana, terdapat beberapa objek daya tarik wisata yang masih belum sesuai. Adapun sarana dan prasarana yang tersedia pada kebanyakan objek daya tarik wisata di Kabupaten Tabalong sudah tersedia, namun masih kurang lengkap. Terdapat 2 objek daya tarik wisata yang tidak memiliki sarana sama sekali yaitu Air Terjun Tabur Berangin dan Danau Undan. Selain itu, juga terdapat 11 objek daya tarik wisata yang memiliki kelengkapan prasarana yaitu Puncak Karamo, Taman Bunga Poska, Taman 10-k, Taman Giat, Taman Bunga dan Buah, Masjid Pusaka, Masjid Islamic Center, Gelar Budaya Dayak Deah, Seribu Cahaya Badudus dan Babarasih Pusaka, Tabalong Etnic Festival, Tari Balian Manaik Manau.

\section{Kesimpulan}

Kemampuan lahan adalah penilaian atas kemampuan lahan untuk penggunaan tertentu yang dinilai masing-masing faktor penghambat. Penggunaan lahan yang tidak sesuai dengan kemampuannya dan tidak dibarengi oleh pengelolaan yang baik akan mempercepat terjadinya degradasi lahan. Apabila sudah mengalami degradasi lahan, maka akan berpengaruh pada tingkat produktivitas lahan yang menurun.

Berdasarakan hasil analisis yang telah dilakukan terhadap 9 jenis SKL didapatkan bahwa klasifikasi kemampuan pengembangan lahan di Kabupaten Tabalong terdiri diri kemampuan pengembangan sangat rendah, rendah, dan sedang. Sementara itu, kemampuan pengembangan lahan pada lingkup Kabupaten Tabalong didominasi dengan kemampuan pengembangan rendah sebesar 205.732 Ha. Sedangkan, luas wilayah terbesar dengan kemampuan pengembangan sedang yang dapat diarahakan sebagai diarahkan kawasan terbangun dengan kegiatan tertentu, terdapat pada Kecamatan Muara Pudak dengan luas 15.502 Ha.

Sedangkan, berdasarkan hasil analisis kesesuaian lahan terhadap 35 objek wisata yang terdapat di Kabupaten tabalong dapat diketahui bahwa terdapat 13 objek daya tarik wisata yang memiliki kesesuaian kemampuan lahan dan fisik, tetapi terdapat 10 objek daya tarik wisata yang tidak sesuai degan kemampuan lahan diantaranya Taman Bunga Poska, Taman 10-K, Taman Giat, Taman Bunga dan Buah, Makam Penghulu Rasyid, Masjid Pusaka, Masjid Islamic Center, Makam Datu Puain, Masjid Pusaka Nurul Iman, dan Seribu Cahaya Badudus dan Babarasih Pusaka.

Rekomendasi untuk kemampuan pengembangan lahan efektif dalam tata ruang Kabupaten Tabalong agar dapat diimplementasikan untuk pengembangan objek daya tarik wisata. Sehingga dalam pengembangan ODTW Kabupaten Tabalong dapat disesuaikan dengan kemampuan lahan yang telah didapatkan. Apabila pengembangan lahan yang tidak sesuai dilakukan, maka akan terjadi degradasi lahan, dan penurunan kualitas dari ODTW Kabupaten Tabalong. Pengembangan sarana dan prasarana ODTW juga sangat penting dilakukan, sehingga ODTW akan semakin berkembang. Hal ini dapat menjadi upaya Kabupaten Tabalong menjadi kawasan pariwisata.

\section{Referensi}

Arsyad, Sitanala. (2010). Konservasi Tanah dan Air Edisi, Edisi Kedua. Bogor: IPB Press.

Dagasou,Roimaltus,dkk. (2019). Kemampuan Lahan dan Pemanfaatan Ruang Pulau Bunaken Manado. Manado: Universitas Sam Ratulanggi.

FAO (Food andAgriculture Organization). (1976). A Framework for LandEvaluation. FAO Soil Bulletin 52. Soil Resources Management andConservation Service Land and Water Development Division.

Peraturan Menteri Pekerjaan Umum No.20/PRT/M.2007 tentang Pedoman Teknik Analisis Fisik Dan Lingkungan, Ekonomi Serta Sosial Budaya dalam Penyusunan Rencana Tata Ruang.

Peraturan Menteri Pekerjaan Umum Nomor 41 Tahun 2007 Tentang Pedoman Kriteria Karakteristik Kawasan Budidaya

Selfie,Luther,dkk. (2013). Klasifikasi Kemampuan Lahan Dengan Menggunakan Sistem Informasi Geografis di Kecamatan Lolak Kabupaten Bolaang Mongondow. Manado: Universitas Sam Ratulangi. 